Article

\title{
Autoinducer Analogs Can Provide Bactericidal Activity to Macrolides in Pseudomonas aeruginosa through Antibiotic Tolerance Reduction
}

\author{
Mizuki Abe ${ }^{1,2}$, Keiji Murakami ${ }^{1,3, *}$, Yuka Hiroshima ${ }^{1}$, Takashi Amoh ${ }^{4}$, Mayu Sebe ${ }^{3}$, Keiko Kataoka ${ }^{2}$ \\ and Hideki Fujii ${ }^{1}$ D
}

1 Department of Oral Microbiology, Institute of Biomedical Sciences, Tokushima University Graduate School, Tokushima 770-8504, Japan; mizukiabu@gmail.com (M.A.); yuka.hiroshima@tokushima-u.ac.jp (Y.H.); hfuji@@tokushima-u.ac.jp (H.F.)

2 Department of Microbiology and Genetic Analysis, Institute of Biomedical Sciences, Tokushima University Graduate School, Tokushima 770-8503, Japan; kataokakeiko@tokushima-u.ac.jp

3 Department of Clinical Nutrition, Faculty of Health Science and Technology, Kawasaki University of Medical Welfare, Kurashiki 701-0193, Japan; sebe@mw.kawasaki-m.ac.jp

4 Department of Dental Hygiene, Mejiro University College, Tokyo 161-8539, Japan; t.amo@mejiro.ac.jp

* Correspondence: murakamik@mw.kawasaki-m.ac.jp; Tel.: +81-86-462-1111 (ext. 55074); Fax: +81-86-463-3508

check for

updates

Citation: Abe, M.; Murakami, K.;

Hiroshima, Y.; Amoh, T.; Sebe, M.; Kataoka, K.; Fujii, H. Autoinducer Analogs Can Provide Bactericidal Activity to Macrolides in Pseudomonas aeruginosa through Antibiotic Tolerance Reduction. Antibiotics 2022, 11, 10. https://doi.org/10.3390/ antibiotics 11010010

Academic Editor: Francesco Imperi

Received: 12 November 2021

Accepted: 14 December 2021

Published: 22 December 2021

Publisher's Note: MDPI stays neutral with regard to jurisdictional claims in published maps and institutional affiliations.

Copyright: (C) 2021 by the authors. Licensee MDPI, Basel, Switzerland. This article is an open access article distributed under the terms and conditions of the Creative Commons Attribution (CC BY) license (https:// creativecommons.org/licenses/by/ $4.0 /)$.

\begin{abstract}
Macrolide antibiotics are used in treating Pseudomonas aeruginosa chronic biofilm infections despite their unsatisfactory antibacterial activity, because they display several special activities, such as modulation of the bacterial quorum sensing and immunomodulatory effects on the host. In this study, we investigated the effects of the newly synthesized $P$. aeruginosa quorum-sensing autoinducer analogs (AIA-1, -2) on the activity of azithromycin and clarithromycin against P. aeruginosa. In the killing assay of planktonic cells, AIA-1 and -2 enhanced the bactericidal ability of macrolides against $P$. aeruginosa PAO1; however, they did not affect the minimum inhibitory concentrations of macrolides. In addition, AIA-1 and -2 considerably improved the killing activity of azithromycin and clarithromycin in biofilm cells. The results indicated that AIA-1 and -2 could affect antibiotic tolerance. Moreover, the results of hydrocarbon adherence and cell membrane permeability assays suggested that AIA- 1 and -2 changed bacterial cell surface hydrophobicity and accelerated the outer membrane permeability of the hydrophobic antibiotics such as azithromycin and clarithromycin. Our study demonstrated that the new combination therapy of macrolides and AIA- 1 and -2 may improve the therapeutic efficacy of macrolides in the treatment of chronic P. aeruginosa biofilm infections.
\end{abstract}

Keywords: Pseudomonas aeruginosa; autoinducer analog; macrolide; antibiotic tolerance

\section{Introduction}

Pseudomonas aeruginosa is an opportunistic pathogen responsible for chronic infections and biofilm formation, which is a major cause of antibiotic treatment failure [1]. P. aeruginosa produces at least three types of the extracellular polymeric substances (EPSs): alginate, Pel, and Psl $[2,3]$. These EPSs play a critical role in biofilm formation and often cause chronic infections such as cystic fibrosis (CF), diffuse panbronchiolitis (DPB), and chronic sinusitis [4,5].

Macrolides are 14-membered (e.g., erythromycin, clarithromycin), 15-membered (e.g., azithromycin), or 16-membered (e.g., josamycin) antibacterial agents, with an antibacterial spectrum mainly against Gram-positive cocci. Recently, 14- and 15-membered macrolides have attracted attention for their "new actions" in addition to antibacterial activity. This "new action" includes the action of macrolides against biofilm infections such as DPB, despite having almost no antibacterial activity against $P$. aeruginosa, the causative agent of DPB [6-8]. It has an immunomodulatory effect on the host and exerts an effect other than antibacterial activity on $P$. aeruginosa [9]. 
In quorum sensing (QS), bacteria sense and respond to their cell density using small diffusible molecules called autoinducers (AI). QS controls several virulence productions [10]. $P$. aeruginosa possesses two signal molecules of N-acylated-homoserine lactones (acylHSL): N-3-oxododecanoyl-homoserine lactone (3-OC12-HSL; OdDHL) and N-butanoylhomoserine lactone (C4-HSL) [11]. We previously demonstrated that the autoinducer 3-OC12-HSL analog-1 (AIA-1) does not inhibit quorum sensing and biofilm formation; however, it enhances the antibacterial activity of biapenem, ofloxacin, and tobramycin in vitro and in vivo [12]. Moreover, it enhances the antibacterial activity against antibioticresistant $P$. aeruginosa strains [13].

This study investigated the combination therapy of AIA and macrolides in planktonic and biofilm cells against $P$. aeruginosa PAO1.

\section{Results}

\subsection{AIA-1 and -2 Do Not Affect Antibiotic Susceptibility}

The structures of AIA-1 (N-(piperidine-4-yl)-dodecanamide) and AIA-2 (N-(pyrrolidine3-yl)-dodecanamide) are shown in Figure 1a,b. The MICs of antibiotics and AIA-1 and -2 are shown in Table 1 . The MICs of AIA- 1 and -2 were 128 and $64 \mu \mathrm{g} / \mathrm{mL}$, respectively, demonstrating unsatisfactory antibacterial activity against $P$. aeruginosa. In the presence of $32 \mu \mathrm{g} / \mathrm{mL}$ AIA-1 and -2, the MICs of the antibiotics did not change, indicating that AIA-1 and -2 did not affect the susceptibility of antibiotics.

(a)<smiles>CCCCCCCCCCCC(=O)NC1CCNCC1</smiles>

(b)<smiles>CCCCCCCCCCCC(=O)NC1CCNC1</smiles>

(c)<smiles>CCCCCCCCCC(=O)CC(=O)NC1CCOC1=O</smiles>

Figure 1. The structure of AIA-1 (N-(piperidine-4-yl)-dodecanamide) (a), and AIA-2 (N-(pyrrolidine-3yl)-dodecanamide) (b), the analog of OdDHL (N-3-oxododecanoyl-homoserine lactone). The structure of OdDHL (c). 
Table 1. Susceptibility to antibiotics and AIAs.

\begin{tabular}{cc}
\hline Antibiotics and AIAs & MIC $(\mu \mathrm{g} / \mathbf{m L})$ \\
\hline AZM & 256 \\
CLR & 128 \\
AIA-1 & 128 \\
AIA-2 & 64 \\
AZM + AIA-1 $(32 \mu \mathrm{g} / \mathrm{mL})$ & 256 \\
AZM + AIA-2 $(32 \mu \mathrm{g} / \mathrm{mL})$ & 256 \\
CLR + AIA-1 $(32 \mu \mathrm{g} / \mathrm{mL})$ & 64 \\
CLR + AIA-2 $(32 \mu \mathrm{g} / \mathrm{mL})$ & 64 \\
\hline
\end{tabular}

AZM; azithromycin, CLR; clarithromycin.

\subsection{Time Killing Assay and $M D K_{9 g}$ for Azithromycin and Clarithromycin}

We examined the effects of the combined use of antibiotics and AIA-1 or -2 on the survival rate of PAO1. The survival rate of P. aeruginosa after $10 \mathrm{~h}$ was more than 1,000,000 and 10,000 times lower with the combination of azithromycin $(256 \mu \mathrm{g} / \mathrm{mL})$ with AIA-1 $(32 \mu \mathrm{g} / \mathrm{mL})$ and AIA-2 $(32 \mu \mathrm{g} / \mathrm{mL})$, respectively, than with azithromycin $(256 \mu \mathrm{g} / \mathrm{mL})$ alone (Figure 2a). The survival rate of P. aeruginosa after $10 \mathrm{~h}$ was more than 1000 times and 10,000 lower with the combination of clarithromycin $(256 \mu \mathrm{g} / \mathrm{mL})$ with AIA-1 $(32 \mu \mathrm{g} / \mathrm{mL})$ and AIA-2 $(32 \mu \mathrm{g} / \mathrm{mL})$, respectively, than with clarithromycin $(512 \mu \mathrm{g} / \mathrm{mL})$ alone (Figure $2 \mathrm{~b}$ ). The combination of AIA- 1 or -2 , with azithromycin or clarithromycin was more effective than azithromycin or clarithromycin alone.

A new parameter, MDK (the minimum duration for killing a certain percentage of the population), was used to quantify antibiotic tolerance. $\mathrm{MDK}_{99}$ represents the minimum duration required for killing 99\% of the population [14]. MDK 99 of azithromycin $(256 \mu \mathrm{g} / \mathrm{mL})$ alone was $8.6 \mathrm{~h}$, and those of the combination of azithromycin $(256 \mu \mathrm{g} / \mathrm{mL})$ with AIA-1 or $-2(32 \mu \mathrm{g} / \mathrm{mL})$ were both $1.5 \mathrm{~h}$ (Figure $2 \mathrm{c})$. MDK 99 of clarithromycin $(512 \mu \mathrm{g} / \mathrm{mL})$ alone was $15.5 \mathrm{~h}$, and that of the combination of clarithromycin $(256 \mu \mathrm{g} / \mathrm{mL})$ with AIA-1 or -2 $(32 \mu \mathrm{g} / \mathrm{mL}$ ) was $3 \mathrm{~h}$ or $1.8 \mathrm{~h}$, respectively (Figure $2 \mathrm{~d}$ ).

(a)

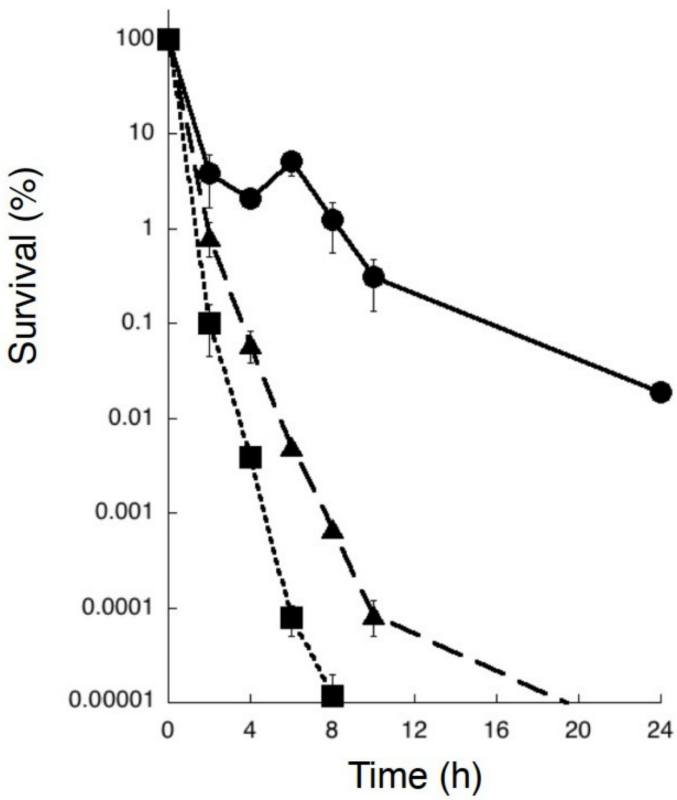

(b)

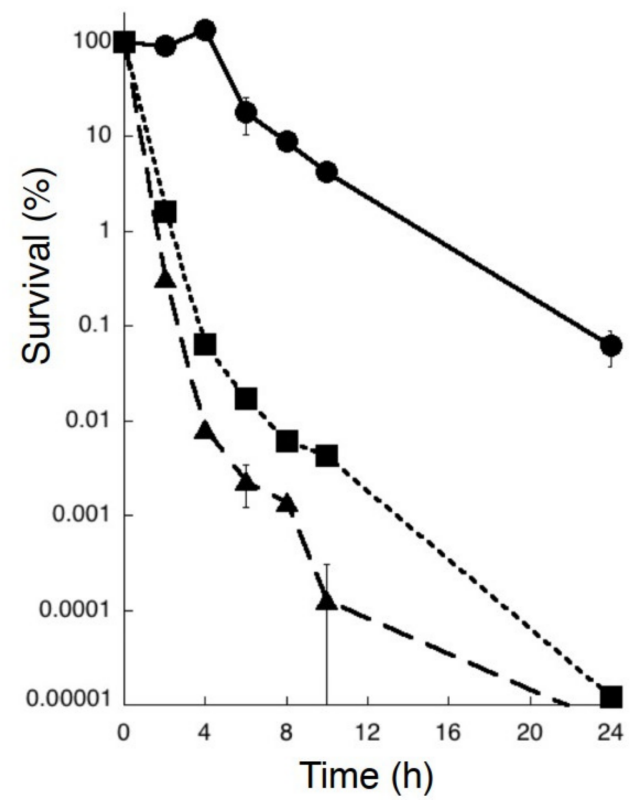

Figure 2. Cont. 
(c)

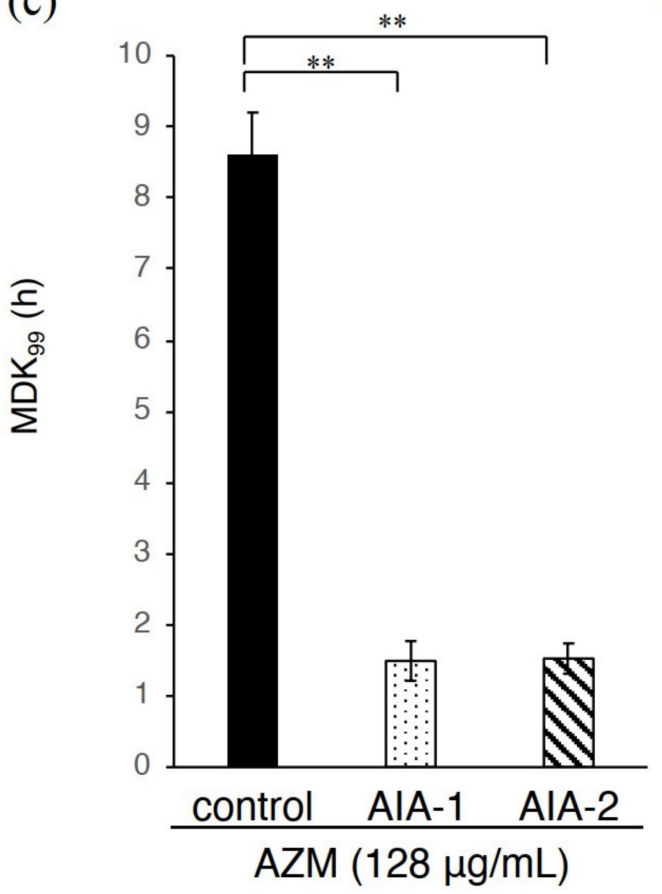

(d)

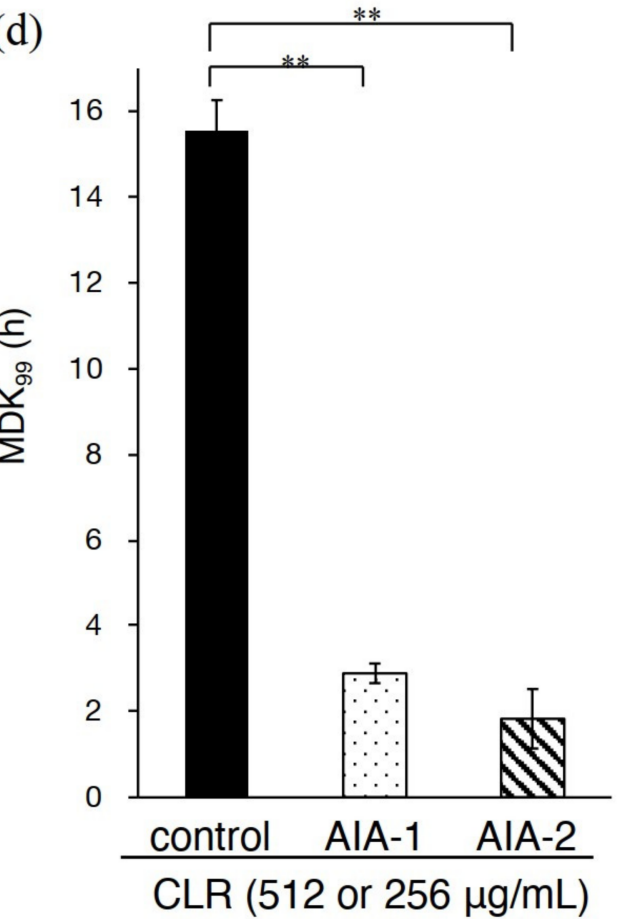

Figure 2. Time-kill assay for PAO1. (a) Time-kill assay for PAO1 in the presence of azithromycin at $256 \mu \mathrm{g} / \mathrm{mL}$ with or without AIA-1 and -2 at $32 \mu \mathrm{g} / \mathrm{mL}$. Azithromycin alone, filled circle on the solid line; azithromycin with AIA-1, a filled square on the dotted line; azithromycin with AIA-2, filled triangle on the dashed line. (b) Time-kill assay for PAO1 in the presence of clarithromycin at 512 or $256 \mu \mathrm{g} / \mathrm{mL}$ with or without AIA-1 or -2 at $32 \mu \mathrm{g} / \mathrm{mL}$. Clarithromycin alone, a filled circle on the solid line; clarithromycin with AIA-1, filled square on the dotted line; clarithromycin with AIA-2, filled triangle on the dashed line. $\mathrm{MDK}_{99}$ was determined by measuring the time to kill $99 \%$ of the population with azithromycin at $256 \mu \mathrm{g} / \mathrm{mL}$ with or without AIA- 1 and -2 at $32 \mu \mathrm{g} / \mathrm{mL}$ (c) and clarithromycin at 512 or $256 \mu \mathrm{g} / \mathrm{mL}$ with or without AIA-1 and -2 at $32 \mu \mathrm{g} / \mathrm{mL}$ (d). Assuming that survival at time 0 was $100 \%, \mathrm{CFU}$ values were converted to percentages. All experiments were performed in triplicate. ${ }^{* *} p<0.01$, (Student's $t$-test). Error bars, SDs for three experiments.

\subsection{AIA-1 and -2 Affect Azithromycin and Clarithromycin Tolerance in Biofilm Cells}

Adding $32 \mu \mathrm{g} / \mathrm{mL}$ AIA-1 and -2 in the killing assay with azithromycin $(256 \mu \mathrm{g} / \mathrm{mL})$ for biofilm resulted in a viable cell number that was approximately 80,000-fold lower than that observed for PAO1 in the presence of azithromycin alone (Figure 3a). Interestingly, the viable cell number of the combined use of even $32 \mu \mathrm{g} / \mathrm{mL}$ azithromycin with AIA1 and -2 was approximately 100-fold lower than that of azithromycin alone. Similar results were obtained when AIA-1 and $-2(32 \mu \mathrm{g} / \mathrm{mL})$ were combined with clarithromycin $(256 \mu \mathrm{g} / \mathrm{mL})$, leading to approximately 100-fold lower viable cell numbers compared to when clarithromycin was used alone (Figure $3 b$ ). These results suggest that AIA-1 and -2 , at a concentration of $32 \mu \mathrm{g} / \mathrm{mL}$, increased the bactericidal activity of azithromycin and clarithromycin against biofilm cells. 
(a)

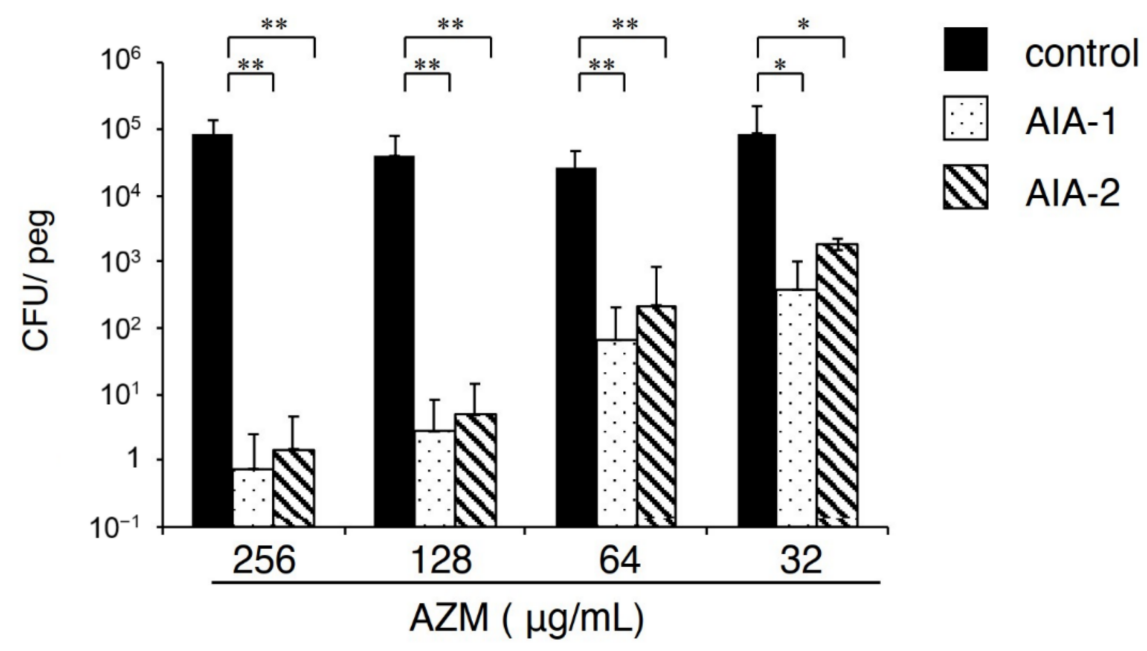

(b)

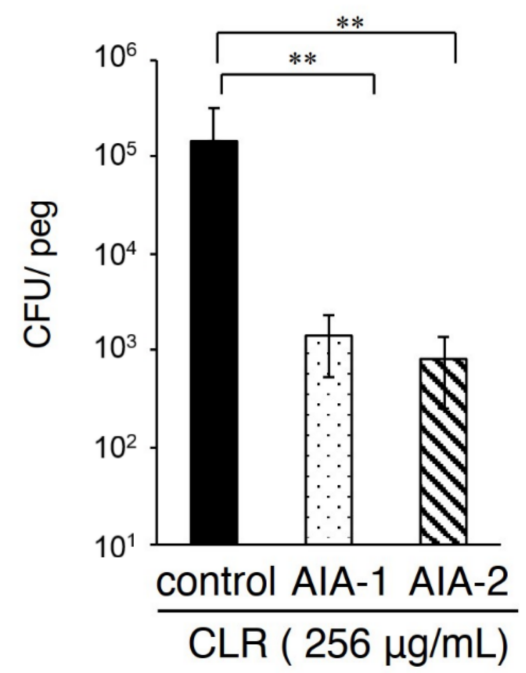

Figure 3. Efficacy of AIA-1 and -2 against PAO1 biofilms. Killing assay for biofilm cells using (a) 256, 128,64 , and $32 \mu \mathrm{g} / \mathrm{mL}$ azithromycin with $32 \mu \mathrm{g} / \mathrm{mL}$ AIA-1 or -2 (b) $256 \mu \mathrm{g} / \mathrm{mL}$ clarithromycin with $32 \mu \mathrm{g} / \mathrm{mL}$ AIA-1 or -2 . The number of CFU per peg was calculated. ${ }^{*} p<0.05,{ }^{* *} p<0.01$ (Student's $t$-test). Error bars, SDs for eight experiments.

\subsection{AIA-1 and -2 Affects Bacterial Hydrophobicity of P. aeruginosa}

To understand the mechanism of AIA-1 and -2 action on antibiotic tolerance, we measured the hydrophobicity of the cell surface. The adsorption rate of PAO1 to hexadecane was $2.5 \%$, whereas it significantly increased to $18 \%$ and $10 \%$ when treated with AIA- 1 and -2 , respectively (Figure 4a). 
(a)

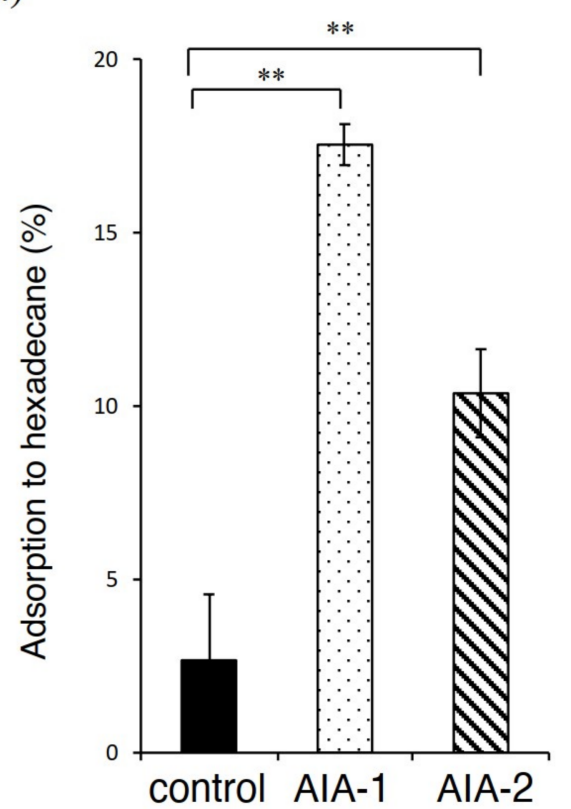

(b)

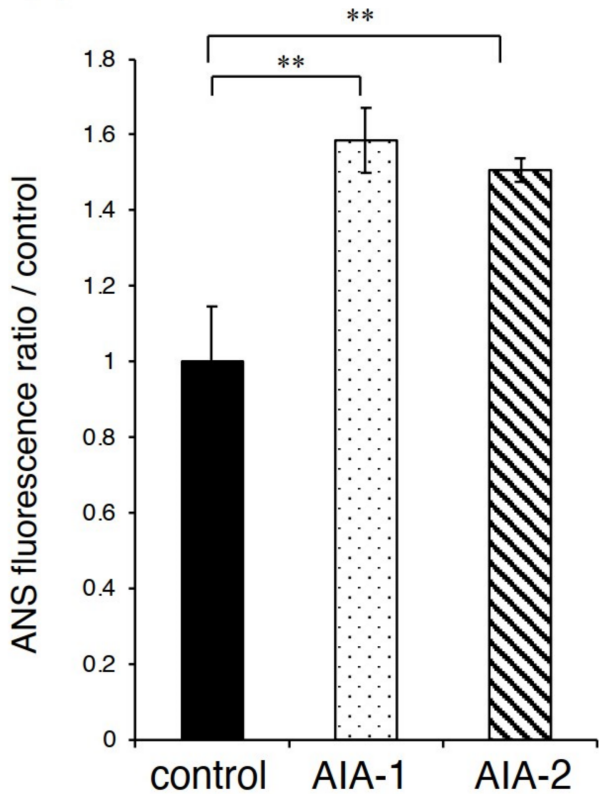

Figure 4. Hydrophobicity of PAO1 treated with AIA-1 or -2. (a) The rate of adsorption to hexadecane (cell-surface hydrophobicity) (b) ANS (8-anilino-1-naphthylenesulfonic acid) fluorescence ratio by treatment with $32 \mu \mathrm{g} / \mathrm{mL}$ AIA- 1 or -2 . ${ }^{* *} p<0.01$ (Student's $t$-test). Error bars, SDs for four experiments.

\subsection{AIA-1 and -2 Treatment Increases ANS Uptake}

To measure the change in cell surface hydrophobicity by AIA-1 and -2, we measured the uptake of the hydrophobic fluorescent probe, ANS. AIA-1 treatment significantly increased ANS fluorescence by approximately $60 \%$, and AIA- 2 treatment increased ANS fluorescence by $40 \%$ (Figure 4 b).

\section{Discussion}

The results of this study show that AIA- 1 and -2 improve the bactericidal activity of azithromycin and clarithromycin by changing the cell surface hydrophobicity of P. aeruginosa, thereby reducing antibiotic tolerance.

Macrolides have been used to treat chronic respiratory infections caused by P. aeruginosa; however, their antibacterial activity against $P$. aeruginosa is unsatisfactory [6-8]. Macrolides have many important functions, including anti-inflammatory [15], antivirulence $[16,17]$, QS inhibition [18,19], and antibacterial activities. Sub-MICs of azithromycin inhibit the production of several QS-regulated virulence factors by interfering with the synthesis of autoinducers [18,19].

We previously reported that AIA-1, which did not inhibit QS, enhanced the antibacterial effects of biapenem in an in vivo mouse acute infection model and in vitro time kill assay, and enhanced the antibacterial effects of other antibiotics such as levofloxacin and tobramycin. These effects were observed not only in planktonic cells, but also in biofilm cells. AIA-1 did not induce changes in the MIC of antibiotics, suggesting that it exerted its effects on antibiotic tolerance without affecting the MIC levels [12]. In this susceptibility test, the MICs for azithromycin and clarithromycin did not change in the presence of AIA-1 and -2 . This result also showed that AIA- 1 and -2 could affect the antibiotic tolerance and enhance the bactericidal activity of macrolides.

Antibiotic tolerance is the ability of bacteria to survive but not grow under antibiotic stress without any gene mutations [20], and it is closely related to the clinical symptoms and prognosis of respiratory tract infections caused by P. aeruginosa [21]. In the present study, the $\mathrm{MDK}_{99}$ of azithromycin or clarithromycin with AIA-1 and -2 was significantly 
shorter compared to that of azithromycin or clarithromycin alone. Although the killing assay is generally performed to evaluate antibiotic tolerance, MDK has been confirmed to be an excellent parameter for the quantification of antibiotic tolerance.

Macrolides are effective mainly against Gram-positive bacteria, but are not sensitive to most Gram-negative bacteria, except for Moraxella catarrhalis, Haemophilus influenzae, and Bacteroides fragilis [22]. In most Gram-negative bacteria, the cell surface is hydrophilic because of the O-antigen of lipopolysaccharide molecules in the outer membrane. There are no pathways across the outer membrane of Gram-negative bacteria for the entry of hydrophobic antibiotics or macrolides. Our study demonstrated that adding AIA-1 and -2 changed the cell surface hydrophobicity and accelerated the outer membrane permeability of hydrophobic antibiotics such as azithromycin and clarithromycin.

Bacterial biofilms are more tolerant to antibiotics compared to planktonic bacteria. However, the mechanisms of antibiotic tolerance in biofilm cells are unknown. We previously reported that the $p s l$ genes, activated by surface adherence through elevated intracellular c-di-GMP levels, confer tolerance to biapenem [23], and carbon metabolism, iron regulation, and stress response play an important role in antibiotic tolerance to biapenem in biofilm cells [24]. Nguyen et al. showed that the antibiotic tolerance of nutrient-limited and biofilm P. aeruginosa is mediated by active responses to starvation [25]. In this study, AIA-1 and -2 surprisingly improved the killing activity of azithromycin and clarithromycin even in biofilm cells. It is still unclear whether this effect is only due to the permeability of macrolides or whether AIA-1 and -2 affect other mechanisms of antibiotic tolerance.

Finally, our study demonstrated that the new combination therapy of macrolides with AIA- 1 and -2 could improve the therapeutic efficacy of the current macrolide therapy for chronic $P$. aeruginosa biofilm infections.

\section{Materials and Methods}

\subsection{Bacterial Strain}

P. aeruginosa PAO1 was used in all the experiments. It was incubated at $37^{\circ} \mathrm{C}$ in lysogeny broth (LB) or on lysogeny agar (LA) plates.

\subsection{Reagents}

Azithromycin was purchased from Meiji Seika Pharma Co., Ltd. (Tokyo, Japan). Clarithromycin was purchased from Taisho Pharmaceutical Holdings Co., Ltd. (Tokyo, Japan).

\subsection{Susceptibility Testing for Planktonic Bacteria}

The minimum inhibitory concentration (MIC) of planktonic bacteria for AIA-1, -2, azithromycin, and clarithromycin were assessed using a standard microbial broth dilution method [26]. In susceptibility assays including both antibiotics and AIA-1 or -2, AIA-1 or -2 were used at a concentration of $32 \mu \mathrm{g} / \mathrm{mL}$.

\subsection{Time Kill Assay and Measuring MDK99}

PAO1 was grown until it displayed an optical density at $600 \mathrm{~nm}\left(\mathrm{OD}_{600}\right)$ of $0.25 \mathrm{in} \mathrm{LB}$ medium. Subsequently, cells were incubated in the presence of azithromycin $(256 \mu \mathrm{g} / \mathrm{mL})$, clarithromycin (512 or $256 \mu \mathrm{g} / \mathrm{mL})$, and / or AIA-1 or $-2(32 \mu \mathrm{g} / \mathrm{mL})$ for various periods of time $(0$ to $24 \mathrm{~h}$ ). Assuming that survival at time 0 was $100 \%$, the colony forming unit (cfu) values were converted to percentages.

MDK (the minimum duration for killing a certain percentage of the population) 99 was measured as the minimum duration required to kill $99 \%$ of the cells from killing curves [14].

\subsection{Biofilm Killing Assay}

The biofilms were grown using the MBEC physiology and genetics assay kit (Innovotech Inc., Edmonton, $\mathrm{AB}, \mathrm{Canada}$ ) for $24 \mathrm{~h}$ at $37^{\circ} \mathrm{C}$ with aeration [27]. In the killing assay for biofilm cells, biofilms were exposed to $32 \mu \mathrm{g} / \mathrm{mL}$ AIA- 1 or -2 at $37^{\circ} \mathrm{C}$ for $1 \mathrm{~h}$. Biofilms were then exposed to 256, 128, 64, and $32 \mu \mathrm{g} / \mathrm{mL}$ azithromycin or $256 \mu \mathrm{g} / \mathrm{mL}$ 
clarithromycin at $37^{\circ} \mathrm{C}$ for $24 \mathrm{~h}$. Subsequently, the biofilms were washed and disrupted by sonication (Branson 3510, Branson Ultrasonics Corp., Brookfield, CT, USA) for $1 \mathrm{~h}$. Viable counts were determined on LA plates, and the number of CFU per peg was calculated.

\subsection{Hydrocarbon Adherence Assay}

PAO1 was grown until it displayed an $\mathrm{OD}_{600}$ of 0.25 in LB medium. Cells were incubated in the presence of AIA- 1 or $-2(32 \mu \mathrm{g} / \mathrm{mL})$ for $4 \mathrm{~h}$. Cells were harvested by centrifugation and resuspended in phosphate urea magnesium sulfate buffer $(\mathrm{pH} 7.1)$ at a turbidity of 0.5 at $660 \mathrm{~nm}$ for the hydrocarbon adherence assay. Cell surface hydrophobicity was estimated using a modification of the hydrocarbon adherence technique described by Rosenberg et al. [28]. Two hundred microliters of hexadecane (Sigma-Aldrich, St. Louis, MO, USA) were added to $3 \mathrm{~mL}$ of microbial suspension in a test tube $(12 \times 105 \mathrm{~mm})$. The test tube was vigorously agitated using a mixer for $60 \mathrm{~s}$ and then allowed to stand.

The turbidity of the aqueous phase was measured using a spectrophotometer, and the hydrophobicity was expressed as the percentage reduction in the initial turbidity of the aqueous suspension.

\subsection{Cell Membrane Permeability Assays}

Cell membrane permeability assays was performed essentially as previously described [29,30]. The fluorescent probe, 8-anilino-1-naphthalenesulfonic acid (ANS; SigmaAldrich, St. Louis, MO, USA), was used to assess the integrity of bacterial cell membrane. ANS is a neutrally charged, hydrophobic probe that fluoresces weakly in aqueous environments but exhibits enhanced fluorescence in nonpolar/hydrophobic environments. PAO1 was grown until it displayed an $\mathrm{OD}_{600}$ of 0.25 in LB medium. Cells were incubated in the presence of AIA-1 or $-2(32 \mu \mathrm{g} / \mathrm{mL})$ for $4 \mathrm{~h}$. Cells were washed and resuspended in $5 \mathrm{mM}$ sodium 4-(2-hydroxyethyl)piperazine-1-ethanesulfonic acid (HEPES, pH 7.2) and $98 \mu \mathrm{L}$ of sample were added to 96-well plate. Subsequently, $2 \mu \mathrm{L}$ of $3 \mathrm{mM}$ ANS were added to each well, and the fluorescence was measured using a spectrophotometer, with fluorescence emission at $510 \mathrm{~nm}$ after excitation at $375 \mathrm{~nm}$.

\subsection{Statistical Analyses}

Data are presented as mean \pm standard deviation (SD). All comparisons between the populations were performed using Student's $t$-test or Fisher's exact test. All statistical analyses were performed using GraphPad PRISM 5.01 (GraphPad Software, Inc., La Jolla, CA, USA). Statistical significance was set at $p<0.05$.

Author Contributions: Conceptualization, K.M.; data curation, M.S.; formal analysis, Y.H.; investigation, M.A.; Visualization, T.A.; writing-original draft, K.M.; writing—review \& editing, K.K. and H.F. All authors have read and agreed to the published version of the manuscript.

Funding: This study was funded by Otsuka Chemical Co., Ltd. of Tokushima, Japan.

Institutional Review Board Statement: Not applicable.

Informed Consent Statement: Not applicable.

Data Availability Statement: The data presented in this study are available on request from the corresponding author.

Acknowledgments: This work was supported by the Otsuka Chemical Co., Ltd. of Tokushima, Japan.

Conflicts of Interest: The funders had no role in the design of the study; in the collection, analyses, or interpretation of data; in the writing of the manuscript, or in the decision to publish the results.

\section{References}

1. Costerton, J.W.; Stewart, P.S.; Greenberg, E.P. Bacterial biofilms: A common cause of persistent infections. Science 1999, 284, 1318-1322. [CrossRef]

2. Kolter, R.; Greenberg, E.P. The superficial life of microbes. Nature 2006, 441, 300-302. [CrossRef] [PubMed] 
3. Ryder, C.; Byrd, M.; Wozniak, D.J. Role of polysaccharides in Pseudomonas aeruginosa biofilm development. Curr. Opin. Microbiol. 2007, 10, 644-648. [CrossRef] [PubMed]

4. Kobayashi, H. Airway biofilm disease. Int. J. Antimicrob. Agents 2001, 17, 351-356. [CrossRef]

5. $\quad$ Rasmussen, J.; Aanæs, K.; Norling, R.; Nielsen, K.G.; Johansen, H.K.; von Buchwald, C. CT of the paranasal sinuses is not a valid indicator for sinus surgery in CF patients. J. Cyst. Fibros. 2012, 11, 93-99. [CrossRef]

6. Tamaoki, J.; Takeyama, K.; Tagaya, E.; Konno, K. Effect of clarithromycin on sputum production and its rheological properties in chronic respiratory tract infections. Antimicrob. Agents Chemother. 1995, 39, 1688-1690. [CrossRef]

7. Fujii, T.; Kadota, J.; Kawakami, K.; Iida, K.; Shirai, R.; Kaseda, M.; Kawamoto, S.; Kohno, S. Long term effect of erythromycin therapy in patients with chronic Pseudomonas aeruginosa infection. Thorax 1995, 50, 1246-1252. [CrossRef]

8. Kudoh, S.; Azuma, A.; Yamamoto, M.; Izumi, T.; Ando, M. Improvement of survival in patients with diffuse panbronchiotitis treated with low-dose erythromycin. Am. J. Respir. Crit. Care Med. 1998, 157, 1829-1832. [CrossRef]

9. Giamarellos-Bourboulis, E. Macrolides beyond the conventional antimicrobials: A class of potent immunomodulators. Int. J. Antimicrob. Agents 2008, 31, 12-20. [CrossRef]

10. Rutherford, S.T.; Bassler, B.L. Baxterial quorum sensing: It's role in virulence and possibilities for its control. Cold Spring Harb. Perspect. Med. 2012, 2, a012427. [CrossRef]

11. Schuster, M.; Greenberg, E.P. A network of networks: Quorum-sensing gene regulation in Pseudomonas aeruginosa. Int. J. Med. Microbiol. 2006, 296, 73-81. [CrossRef] [PubMed]

12. Amoh, T.; Murakami, K.; Kariyama, R.; Hori, K.; Viducic, D.; Hirota, K.; Igarashi, J.; Suga, H.; Parsek, M.R.; Kumon, H.; et al. Effects of an autoinducer analogue on antibiotic tolerance in Pseudomonas aeruginosa. J. Antimicrob. Chemother. 2017, 72, 2230-2240. [CrossRef] [PubMed]

13. Amoh, T.; Murakami, K.; Kariyama, R.; Hori, K.; Irie, Y.; Viducic, D.; Hirota, K.; Igarashi, J.; Suga, H.; Kumon, H.; et al. A Pseudomonas aeruginosa quorum-sensing autoinducer analog enhances the activity of antibiotic resistant strains. J. Med. Investig. 2017, 64, 101-109. [CrossRef] [PubMed]

14. Brauner, A.; Shoresh, N.; Fridman, O.; Balaban, N.Q. An experimental framework for quantifying bacterial tolerance. Biophys. J. 2017, 112, 2664-2671. [CrossRef]

15. Labro, M. Anti-inflammatory of macrolides: A new therapeutic potential? J. Antimicrob. Chemother. 1998, 41, 37-46. [CrossRef] [PubMed]

16. Kawamura-Sato, K.; Iinuma, Y.; Hasegawa, T.; Horii, T.; Yamashino, T.; Ohta, M. Effect of subinhibitory concentrations of macrolides on expression of flagellin in Pseudomonas aeruginosa and Proteus mirabilis. Antimicrob. Agents Chemother. 2000, 44, 2869-2872. [CrossRef]

17. Mizukane, R.; Hirakata, Y.; Kaku, M.; Ishii, Y.; Furuya, N.; Ishida, K.; Koga, H.; Kohno, S.; Yamaguchi, K. Comparative in vitro exoenzyme-suppressing activities of azithromycin and other macrolide antibiotics against Pseudomonas aeruginosa. Antimicrob. Agents Chemother. 1994, 38, 528-533. [CrossRef]

18. Tateda, K.; Comte, R.; Pechere, J.-C.; Köhler, T.; Yamaguchi, K.; Van Delden, C. Azithromycin inhibits quorum sensing in Pseudomonas aeruginosa. Antimicrob. Agents Chemother. 2001, 45, 1930-1933. [CrossRef]

19. Favre-Bonte, S.; Kohler, T.; Delden, V. Biofilm formation by Pseudomonas aeruginosa: Role of the C4-HSL cell-to-cell signal and inhibition by azithromycin. J. Antimicrob. Chemother. 2003, 52, 598-604. [CrossRef]

20. Keren, I.; Kaldalu, N.; Spoering, A.; Wang, Y.; Lewis, K. Persister cells and tolerance to antimicrobials. FEMS Microbiol. Lett. 2004, 230, 13-18. [CrossRef]

21. Azuma, M.; Murakami, K.; Murata, R.; Kataoka, K.; Fujii, H.; Miyake, Y.; Nishioka, Y. Clinical significance of carbapenem-tolerant Pseudomonas aeruginosa isolated in the respiratory tract. Antibiotics 2020, 9, 626. [CrossRef] [PubMed]

22. Gotoh, N.; Tanaka, S.; Nishino, T. Susceptibility to hydrophobic antimicrobial agents and cell surface hydrophobicity in Branhamella catarrhalis. FEMS Microbiol. Lett. 1989, 59, 211-214. [CrossRef]

23. Murakami, K.; Ono, T.; Viducic, D.; Somiya, Y.; Kariyama, R.; Hori, K.; Amoh, T.; Hirota, K.; Kumon, H.; Parsek, M.R.; et al Role of psl genes in antibiotic tolerance of adherent Pseudomonas aeruginosa. Antimicrob. Agents Chemother. 2017, 61, e02587-16. [CrossRef] [PubMed]

24. Murakami, K.; Ono, T.; Noma, Y.; Minase, I.; Amoh, T.; Irie, Y.; Hirota, K.; Miyake, Y. Explorative gene analysis of antibiotic tolerance-related genes in adherent and biofilm cells of Pseudomonas aeruginosa. J. Infect. Chemother. 2017, 23, 271-277. [CrossRef] [PubMed]

25. Nguyen, D.; Joshi-Datar, A.; Lepine, F.; Bauerle, E.; Olakanmi, O.; Beer, K.; McKay, G.; Siehnel, R.; Schafhauser, J.; Wang, Y.; et al. Active starvation responses mediate antibiotic tolerance in biofilms and nutrient-limited bacteria. Science 2011, 334, 982-986. [CrossRef]

26. Clinical and Laboratory Standards Institute. Methods for Dilution Antimicrobial Susceptibility Tests for Bacteria that Grow Aerobically. Approved Standard, 8th ed.; CLSI document M07-A8; Clinical and Laboratory Standards Institute: Wayne, PA, USA, 2009.

27. Ceri, E.; Olson, M.E.; Stremick, C.; Read, R.R.; Morck, D.; Buret, A. The Calgary biofilm device: New technology for rapid determination of antibiotic susceptibilities of bacterial biofilms. J. Clin. Microbiol. 1999, 37, 1771-1776. [CrossRef]

28. Rosenberg, M.; Gutnick, D.; Rosenberg, E. Adherence of bacteria to hydrocarbons: A simple method for measuring cell-surface hydrophobicity. FEMS Microbiol. Lett. 1980, 9, 29-33. [CrossRef] 
29. Lamers, R.P.; Cavallari, J.F.; Burrows, L.L. The efflux inhibitor Phenylalanine-Arginine Beta-Naphthylamide (Pa $\beta N)$ permeabilizes the outer membrane of Gram-negative bacteria. PLoS ONE 2013, 8, e60666.

30. Loh, B.; Grant, C.; Hancock, R.E.W. Use of the fluorescent probe 1-N-phenylnaphthylamine to study the interactions of aminoglycoside antibiotics with the outer membrane of Pseudomonas aeruginosa. Antimicrob. Agents Chemother. 1984, 26, 546-551. [CrossRef] 